\title{
Corrigendum: COVID-19 Confinement and Health Risk Behaviors in Spain
}

\begin{abstract}
Rubén López-Bueno ${ }^{1,2 *}$, Joaquín Calatayud ${ }^{2,3}$, José Casaña ${ }^{3}$, José A. Casajús ${ }^{4}$, Lee Smith ${ }^{5}$, Mark A. Tully ${ }^{6}$, Lars L. Andersen ${ }^{2}$ and Guillermo F. López-Sánchez ${ }^{7 *}$
\end{abstract}

${ }^{1}$ Department of Physical Medicine and Nursing, University of Zaragoza, Zaragoza, Spain, ${ }^{2}$ National Research Centre for the Working Environment, Copenhagen, Denmark, ${ }^{3}$ Exercise Intervention for Health Research Group (EXINH-RG), Department of Physiotherapy, University of Valencia, Valencia, Spain, ${ }^{4}$ Faculty of Health Sciences, University of Zaragoza, Zaragoza, Spain, ${ }^{5}$ Cambridge Centre for Sport and Exercise Science, Anglia Ruskin University, Cambridge, United Kingdom, ${ }^{6}$ Institute of Mental Health Sciences, School of Health Sciences, Ulster University, Belfast, United Kingdom, ${ }^{7}$ Faculty of Sport Sciences, University of Murcia, Murcia, Spain

Keywords: modifiable risk factors, social isolation, Spain, adults, COVID-19

\section{A Corrigendum on}

\section{OPEN ACCESS}

Approved by:

Frontiers Editorial Office,

Frontiers Media SA, Switzerland

${ }^{*}$ Correspondence:

Rubén López-Bueno

rlopezbu@unizar.es

Guillermo F. López-Sánchez gfls@um.es

Specialty section:

This article was submitted to

Health Psychology,

a section of the journal

Frontiers in Psychology

Received: 05 October 2021 Accepted: 06 October 2021 Published: 04 November 2021

Citation:

López-Bueno R, Calatayud J, Casaña J, Casajús JA, Smith L, Tully MA, Andersen LL and López-Sánchez GF (2021) Corrigendum: COVID-19 Confinement and Health Risk Behaviors in Spain.

Front. Psychol. 12:789989. doi: 10.3389/fpsyg.2021.789989
COVID-19 Confinement and Health Risk Behaviors in Spain

by López-Bueno, R., Calatayud, J., Casaña, J., Casajús, J. A., Smith, L., Tully, M. A., Andersen L. L., López-Sánchez G. F. (2020). Front. Psychol. 11:1426. doi: 10.3389/fpsyg.2020.01426

In the original article, the reference for Chen et al. (2009) was incorrectly written as "Chen, P., Mao, L., Nassis, G. P., Harmer, P., Ainsworth, B. E., and Li, F. (2009). Wuhan coronavirus (2019-nCoV): the need to maintain regular physical activity while taking precautions. J. Sport Health Sci. 9, 103-104. doi: 10.1016/j.jshs.2020.02.001". It should be "Chen, P., Mao, L., Nassis, G. P., Harmer, P., Ainsworth, B. E., and Li, F. (2020). Coronavirus disease (COVID-19): The need to maintain regular physical activity while taking precautions. J. Sport Health Sci. 9, 103-104. doi: 10.1016/j.jshs.2020.02.001".

The authors apologize for this error and state that this does not change the scientific conclusions of the article in any way. The original article has been updated.

\section{REFERENCES}

Chen, P., Mao, L., Nassis, G. P., Harmer, P., Ainsworth, B. E., and Li, F. (2020). Coronavirus disease (COVID-19): The need to maintain regular physical activity while taking precautions. J. Sport Health Sci. 9, 103-104. doi: 10.1016/j.jshs.2020.02.001

Publisher's Note: All claims expressed in this article are solely those of the authors and do not necessarily represent those of their affiliated organizations, or those of the publisher, the editors and the reviewers. Any product that may be evaluated in this article, or claim that may be made by its manufacturer, is not guaranteed or endorsed by the publisher.

Copyright () 2021 López-Bueno, Calatayud, Casaña, Casajús, Smith, Tully, Andersen and López-Sánchez. This is an open-access article distributed under the terms of the Creative Commons Attribution License (CC BY). The use, distribution or reproduction in other forums is permitted, provided the original author(s) and the copyright owner(s) are credited and that the original publication in this journal is cited, in accordance with accepted academic practice. No use, distribution or reproduction is permitted which does not comply with these terms. 